\title{
Do patients with celiac disease patients differ from those with concurrent celiac disease with type 1 diabetes mellitus?
}

\author{
Ashu Rastogi ${ }^{1 *}$, Sanjay Kumar², Bhadada Rakesh Kochhar $^{3}$ \\ From 7th APPES Biennial Scientific Meeting \\ Nusa Dua, Bali. 14-17 November 2012
}

\section{Background and objectives}

Celiac disease (CD) and type 1 diabetes mellitus (T1DM) share common genetic loci. Patients with T1DM developing CD may remain asymptomatic and some of the common symptoms of CD may be considered as part of the chronic complications of diabetes like gastrointestinal intolerance, diarrhea, nocturnal diarrhea, alternate diarrhea and constipation.

There are no reports on comparison of presenting features of patients with $C D$ and those with $C D$ and T1DM together. The present study was planned to compare clinical, biochemical and hormonal profile of patients of $\mathrm{CD}$ and $\mathrm{CD}$ with T1DM.

\section{Patients and methods}

Consecutive CD patients with and without T1DM $\leq 20$ years seen by us were evaluated clinically and underwent thyroid, gonadal function tests (where applicable) and serum cortisol, besides routine hemogram and biochemical tests. Patients were subjected to screening for CD by anti tissue transglutaminase antibodies (tTGAb) and those positive were subjected to endoscopy of descending part of the duodenum, and 3 biopsies were taken. Histological interpretation was done by an experienced pathologist and recorded as per modified Marsh classification [1]. Patients were diagnosed to have $\mathrm{CD}$ as per modified ESPGHAN criteria [2] and T1DM as per ADA position statement [3]. All patients received gluten free diet (GFD) and / or diabetic diet. Patients with $\mathrm{CD}$ alone (group A) were compared with those having CD with T1DM (Group B).

\section{Results}

109 patients (57 males) with mean age of $14.9 \pm 2.9$ year fulfilled the eligibility criteria. $23(21.1 \%)$ had T1DM

Table 1 Symptoms in patients with celiac disease alone and celiac disease with type 1 diabetes mellitus

\begin{tabular}{llllll}
\hline S.No & Clinical Features & All Patients (N= 109) & CD Alone (Group A, N=86) & CD+T1DM (Group B, N=23) & $P$ value (Group A\&B)) \\
\hline 1. & Short stature & $77.1 \%$ & $87 \%$ & $40.9 \%$ & .000 \\
\hline 2. & Diarrhoea & $56.9 \%$ & $40.7 \%$ & $50 \%$ & .431 \\
\hline 3. & Constipation & $4.6 \%$ & $3.5 \%$ & $9.5 \%$ & .246 \\
\hline 4. & Anemia & $70.6 \%$ & $80.9 \%$ & $45 \%$ & .001 \\
\hline 5. & Delayed Puberty & $52.3 \%$ & $61.9 \%$ & $29.4 \%$ & .014 \\
\hline 6. & Weight loss & $55 \%$ & $61.9 \%$ & $45 \%$ & .168 \\
\hline 7. & Hypothyroidism & $8.2 \%$ & $8.1 \%$ & $5 \%$ & .788 \\
\hline 8. & Rickets & $3.7 \%$ & $3.5 \%$ & $4.3 \%$ & .096 \\
\hline 9. & Goitre & $19.3 \%$ & $20.9 \%$ & $13 \%$ & .704 \\
\hline 10. & Hypoadrenalism & $0.9 \%$ & $1.2 \%$ & $0 \%$ & .246 \\
\hline
\end{tabular}

${ }^{1}$ Senior Resident, Deptt. Of Endocrinology, PGIMER, Chandigarh, India

Full list of author information is available at the end of the article

(c) 2013 Rastogi et al; licensee BioMed Central Ltd. This is an Open Access article distributed under the terms of the Creative Commons 
Table 2 Laboratory parameters of patients with celiac disease alone and celiac disease with type 1 diabetes mellitus.

\begin{tabular}{|c|c|c|c|c|c|}
\hline S.No & Biochemical Parameters & All Patients $(\mathrm{N}=109)$ & CD Alone (Group A, N=86) & CD+T1DM (Group B, N=23) & $P$ value (Group A\&B)) \\
\hline 1. & Serum IgA tTG (mIU/L) & $123.2 \pm 110.9$ & $118.3 \pm 112.9$ & $139.5 \pm 111.1$ & .433 \\
\hline 2. & Hemoglobin $(\mathrm{gm} / \mathrm{dl})$ & $8.6 \pm 2.6$ & $8.3 \pm 2.4$ & $10.1 \pm 3.2$ & .018 \\
\hline 3. & $\mathrm{~T} 3$ & $1.3 \pm 0.43$ & $1.3 \pm 0.4$ & $1.4 \pm 0.6$ & \\
\hline 4. & $\mathrm{~T} 4$ & $8.1 \pm 2.6$ & $8.1 \pm 2.7$ & $7.7 \pm 3.1$ & \\
\hline 5. & $\mathrm{TSH}(\mathrm{m} \mid \mathrm{U} / \mathrm{L})$ & $9.7 \pm 34.5$ & $7.1 \pm 21.7$ & $22.4 \pm 69.5$ & .146 \\
\hline 6. & $\mathrm{LH}(\mathrm{m} / \mathrm{U} / \mathrm{L})$ & $2.5 \pm 2.6$ & $2.6 \pm 2.8$ & $1.9 \pm 1.8$ & .596 \\
\hline 7. & Calcium (mg/dl) & $9.35 \pm 1.87$ & $8.9 \pm 0.9$ & $9.4 \pm 1.9$ & \\
\hline 8. & Phosphate (mg/dl) & $4.7 \pm 1.0$ & $4.7 \pm 1.0$ & $4.4 \pm 0.83$ & \\
\hline 9. & ALP(IU/L) & $118.0 \pm 108.4$ & $110.2 \pm 106.4$ & $116.6 \pm 129.5$ & \\
\hline 10. & Albumin (gm/dl) & $4.0 \pm 0.6$ & $4.05 \pm 0.7$ & $4.3 \pm 0.5$ & \\
\hline 11. & SGOT & $39.2 \pm 26.5$ & $32.8 \pm 16.8$ & $39.7 \pm 42.1$ & \\
\hline 12. & SGPT & $36.3 \pm 31.2$ & $28.6 \pm 15.6$ & $34.2 \pm 58.0$ & \\
\hline
\end{tabular}

and $\mathrm{CD}$ while $\mathrm{CD}$ alone was present in 86 subjects. The age at diagnosis of CD was younger $(11.5 \pm 4.6$ vs $13.8 \pm$ $3.4 \mathrm{yr} ; \mathrm{p}<0.05)$ and the lag period between symptoms and diagnosis of CD was shorter $(20.2 \pm 31.8$ vs $56.1 \pm$ 42.4 months; $\mathrm{p}<0.05)$ in those with Group B. Detailed clinical features of patients in two groups are given in Table 1 and laboratory parameters are enumerated in Table 2. Comparing the clinical features in between groups, short stature ( $87 \%$ versus $40.9 \%$, p < 0.0001$)$, anemia (80.9\% versus $45 \%, \mathrm{p}<0.001)$ and delayed puberty (61.9\% versus $29.4 \%, p<0.014$ ) were significantly more common in the Group A. However, diarrhea, constipation and weight loss were comparable in both the groups.

\section{Conclusions}

Present study suggests that patients with celiac disease alone are more symptomatic and associated with more biochemical abnormalities compared to those with celiac disease and T1DM. It will be worthwhile to plan a prospective study with long duration of follow up and more number of patients in both groups to further validate the results.

\section{Authors' details}

${ }^{1}$ Senior Resident, Deptt. Of Endocrinology, PGIMER, Chandigarh, India.

${ }^{2}$ Associate Professor, Deptt. Of Endocrinology, PGIMER, Chandigarh, India.

${ }^{3}$ Professor, Deptt. Of Gastroenterology, PGIMER, Chandigarh, India.

Published: 3 October 2013

\section{References}

1. Marsh MN, Crowe PT: Morphology of the mucosal lesion in gluten sensitivity. Ballieres Clin Gastroenterol 1995, 9:273-293.

2. Walker-Smith JA, Sandhu BK, Isolauri $E$, et al: Revised criteria for the diagnosis of celiac disease, report of the working group of the European Society of Pediatric Gastroenterology. Arch Dis Child 1990, 65:909-11.

3. Standards of Medical Care in Diabetes-2011. Diabetes Care 2011, 34 S11-S61.
doi:10.1186/1687-9856-2013-S1-030

Cite this article as: Rastogi et al: Do patients with celiac disease patients differ from those with concurrent celiac disease with type 1 diabetes mellitus? International Journal of Pediatric Endocrinology 2013 2013(Suppl 1):O30.
Submit your next manuscript to BioMed Central and take full advantage of:

- Convenient online submission

- Thorough peer review

- No space constraints or color figure charges

- Immediate publication on acceptance

- Inclusion in PubMed, CAS, Scopus and Google Scholar

- Research which is freely available for redistribution 